\title{
PERBEDAAN HASIL BELAJAR SISWA MELALUI PENDEKATAN KONVENSIONAL DENGAN PENDEKATAN SAINTIFIK PADA KOMPETENSI DASAR FUNGSI MANAJEMEN SISWA KELAS X DI SMA NEGERI 4 JEMBER TAHUN AJARAN 2016/2017
}

\author{
Linda Fatmawati ${ }^{1}$, Sukidin ${ }^{1}$, Bambang Suyadi ${ }^{1}$ \\ ${ }^{1}$ Program Studi Pendidikan, Fakultas Keguruan dan Ilmu Pendidikan, Universitas Jember \\ e-mail: skdn2016@yahoo.com
}

\begin{abstract}
Abstrak
Penelitian ini bertujuan untuk mengetahui perbedaan yang signifikan hasil belajar siswa yang diajar melalui pendekatan saintifik dengan pendekatan konvensional pada kompetensi dasar fungsi manajemen siswa kelas $\mathrm{X}$ di SMA Negeri 4 Jember Tahun Ajaran 2016/207 sehingga penelitian ini merupakan jenis penelitian komparasional, dimana subyek yang diteliti adalah siswa kelas X. Penentuan lokasi penelitian menggunakan metode purposive. Populasi dalam penelitian ini adalah seluruh siswa kelas X, mulai dari kelas X MIPA 1 sampai kelas X Sos 2. Sampel yang digunakan adalah kelas X Sos 1 sebagai kelas Eksperimen yang menerapkan pendekatan saintifik dan kelas X Sos 2 sebagai kelas kontrol yang menerapkan pendekatan konvensional. Metode pengumpulan data yang digunakan adalah metode tes, observasi, wawancara, dan dokumen. Teknik analisis data yang digunakan dalam penelitian ini adalah Uji Ttest. Hasil uji analisis data pada tes dengan taraf signifikan 5\% dan db 70 diperoleh ttest $=5,556$ yang melebihi nilai ttabel $=1,994$. Hal ini berarti terdapat perbedaan yang siginifikan hasil belajar siswa yang diajar menggunakan pendekatan saintifik dengan pendekatan konvensional,dimana hasil belajar siswa pada kelas yang menerapkan pendekatan saintifik sebesar 82,36 sedangkan hasil belajar siswa pada kelas yang menerapkan pendekatan konvensional sebesar 72,22. Kelas yang menerapkan pendekatan saintifik hasil belajarnya lebih besar 10,14 daripada kelas yang menerapkan pendekatan konvensional. Kesimpulan dari penelitian ini adalah terdapat perbedaan yang signifikan hasil belajar siswa yang diajar menggunakan pendekatan saintifik dengan pendekatan konvensional pada kompetensi dasar fungsi manajemen siswa kelas X di SMA Negeri 4 Jember Tahun Ajaran 2016/2017. Saran yang dapat peneliti sumbangkan dari penelitian ini adalah guru dapat mengintensifkan penggunaan pendekatan saintifik dalam pembelajaran, karena dilihat dari hasil belajar siswa pada kelas eksperimen lebih tinggi dibandingkan dengan kelas kontrol.
\end{abstract}

Kata Kunci: Pendekatan konvensional, pendekatan saintifik, hasil belajar

\section{PENDAHULUAN}

Perubahan merupakan hal yang harus terjadi dalam bidang pendidikan. Pada tahun 2013, di Indonesia terjadi pergantian kurikulum, yaitu dari Kurikulum Tingkat Satuan Pendidikan (KTSP) ke Kurikulum 2013. Pendekatan yang diterapkan dalam Kurikulum Tingkat Satuan Pendidikan adalah pendekatan konvensional, sedangkan pendekatan pembelajaran yang harus digunakan dalam penerapan Kurikulum 2013 adalah pendekatan santifik. Namun, meskipun sebuah sekolah sudah ditetapkan kurikulum 2013 guru-guru masih terbiasa menerapkan pendekatan konvensional dalam proses pembelajaran.

Berdasarkan observasi yang dilakukan oleh peneliti di SMA Negeri 4 Jember yaitu SMA Negeri 4 Jember merupakan salah satu sekolah menengah atas yang sudah menerapkan kurikulum 2013. Namun, setelah peneliti melakukan wawancara kepada salah satu guru ekonomi di SMA Negeri 4 Jember diperoleh informasi bahwa meskipun sekolah tersebut sudah ditetapkan kurikulum 2013 namun guru-guru disekolah tersebut masih menerapkan dua pendekatan yaitu pendekatan konvensional dan pendekatan saintifik. Hal tersebut dilatarbelakangi dengan beberapa alasan. Salah satu alasan guru masih menerapkan pendekatan konvensional yaitu penerapan pendekatan konvensional lebih mudah 
dan tidak membebani guru, karena dalam penerapan pendekatan konvensional tugas guru hanya ceramah dan siswa mendengarkan. Sedangkan alasan guru menerapkan pendekatan saintifik dalam proses pembelajaran adalah sebagai variasi dalam pembelajaran, agar siswa tidak merasa jenuh.

Pembelajaran yang dilakukan dengan pendekatan konvensional ditandai dengan ceramah yang diiringi dengan penjelasan oleh guru, tanya jawab dan penugasan. Pembelajaran konvensional (tradisional) pada umumnya memiliki kekhasan tertentu, misalnya lebih mengutamakan hafalan daripada pengertian, mengutamakan hasil daripada proses, dan pengajaran berpusat pada guru. Hal ini sesuai dengan pendapat Majid (2014:165), yang menyatakan bahwa "Pendekatan Konvensional merupakan pembelajaran dalam konteks klasikal yang sudah terbiasa dilakukan dan sifatnya berpusat pada guru, sehingga pelaksanaannya kurang memerhatikan keseluruhan situasi belajar". Pembelajaran dengan pendekatan konvensional dilakukan dengan langkah guru menyampaikan semua tujuan pembelajaran yang harus dicapai oleh siswa, selanjutnya guru menyampaikan materi pelajaran dengan cara ceramah diiringi dengan penjelasan, siswa mendengarkan dengan seksama penjelasan dari guru dan mencatat hal-hal yang dirasa penting, setelah itu guru memberikan umpan balik kepada siswa dengan melakukan tanya jawab, dan terakhir guru memberikan tugas yang harus dikerjakan oleh siswa.

Pendekatan saintifik yaitu pendekatan baru yang diterapkan dalam kurikulum 2013. Pendekatan saintifik merupakan pendekatan yang bercirikan adanya kegiatan siswa yaitu mengamati, menanya, mengumpulkan data, mengasosiasi dan mengkomunikasikan. Hal ini sesuai dengan pendapat Fadlillah (2014:176) bahwa "Pendekatan scientific ialah pendekatan pembelajaran yang dilakukan melalui proses mengamati (observing), menanya (questioning), mencoba (exerimenting), menalar (associating), dan mengkomunikasikan (communicating)". Sani (2015:50) menyatakan "Pendekatan saintifik berkaitan erat dengan metode saintifik".Dalam pendekatan saintifik siswa mencari sendiri informasi-informasi yang berkaitan dengan materi pelajaran, selanjutnya siswa menyimpulkan informasi yang telah didapat. Dalam proses pembelajaran yang menerapkan pembelajaran saintifik siswa akan terlibat aktif dalam aktivitas belajar, seperti kegiatan mengamati, menanya, mengumpulkan data, mengasosiasi dan mengkomunikasikan. Sehingga pembelajaran tidak hanya dominasi oleh guru, tetapi siswa juga berkesempatan untuk mengemukakan pendapat dan dapat memecahkan masalah sendiri. Menurut Abidin (2014:130), karakteristik pendekatan pembelajaran saintifik adalah sebagai berikut: Objektif, Faktual, Sistematis, Bermetode, Cermat dan tepat, Logis, Aktual, Disinterested, Unsupported opinion, Verifikatif. Pembelajaran yang dilakukan dengan menerapkan pendekatan saintifik interaksi siswa dengan siswa, maupun siswa dengan guru akan berjalan dengan baik. Siswa juga tidak akan bergantung pada guru, karena mereka dapat mendapatkan informasi dari berbagai sumber. Siswa juga dapat bekerja sama dengan kelompoknya untuk memecahkan suatu masalah.

Kedua pendekatan tersebut baik pendekatan saintifik maupun pendekatan konvensional tujuannya sama, yaitu sama-sama memberikan pemahaman kepada para siswa, namun dari kedua pendekatan pembelajaran tersebut langkah-langkah pelaksanaannya berbeda. Pendekatan saintifik dan pendekatan konvensional tersebut diterapkan oleh satu guru, namun penerapannya dilakukan di kelas yang berbeda dengan tingkat kemampuan siswa yang sama. Tujuan guru tersebut menerapkan pendekatan saintifik dan pendekatan konvensional adalah untuk mengetahui pendekatan mana yang lebih efektif. Apakah pendekatan saintifik lebih efektif dibandingkan pendekatan konvensional atau justru sebaliknya, pendekatan konvensional lebih efektif daripada pendekatan saintifik.

Berdasarkan latar belakang diatas, maka rumusan masalah dalam penelitian ini adalah adakah perbedaan yang signifikan antara hasil belajar siswa yang diajar melalui pendekatan saintifik dengan pendekatan konvensional pada kompetensi dasar fungsi manajemen siswa kelas X SMA Negeri 4 Jember tahun ajaran 2016/2017. Berdasarkan rumusan masalah tersebut, maka tujuan penelitian ini adalah untuk mengetahui perbedaan yang signifikan antara hasil belajar siswa yang diajar melalui 
pendekatan saintifik dengan pendekatan konvensional pada kompetensi dasar fungsi manajemen siswa kelas X SMA Negeri 4 Jember tahun ajaran 2016/2017.

\section{METODE}

Jenis penelitian ini merupakan penelitian komparasional yang bertujuan untuk mengetahui perbedaan yang signifikan hasil belajar siswa yang diperoleh melalui pendekatan saintifik dengan pendekatan konvensional pada kompetensi dasar fungsi manajemen siswa kelas X di SMA Negeri 4 Jember. Subyek yang diteliti adalah siswa kelas X. Metode penentuan lokasi menggunakan metode Purposive dengan menentukan lokasi SMA Negeri 4 Jember sebagai lokasi penelitian. Populasi dalam penelitian ini adalah siswa kelas X MIPA 1, X MIPA 2, X MIPA 3, X MIPA 4, X MIPA 5, X MIPA 6, $\mathrm{X}$ Sos 1 , dan $\mathrm{X}$ Sos 2. Sampel yang digunakan adalah kelas $\mathrm{X}$ Sos 1 sebagai kelas eksperimen yang menerapkan pendekatan saintifik dan kelas X Sos 2 sebagai kelas kontrol yang menerapkan pendekatan konvensional. Metode pengumpulan data yang digunakan adalah metode tes, observasi, wawancara, dan dokumen. Teknik analisis data yang digunakan dalam penelitian ini adalah Uji test.

\section{HASIL DAN PEMBAHASAN}

\section{Hasil Penelitian}

Hasil Uji Validitas Tes

Hasil uji validitas tes dengan kriteria yang ditetapkan valid tidaknya suatu tes dalam penelitian ini adalah $\mathrm{r}$ hitung > $\mathrm{r}$ tabel dengan taraf signifikansi 5\% dapat dilihat pada tabel sebagai berikut:

Tabel 4.1 Hasil Uji Validitas Soal Tes

\begin{tabular}{cccc}
\hline No. Soal & r hitung & r tabel & Hasil Uji \\
\hline 1 & 0,727 & 0,235 & Valid \\
\hline 2 & 0,800 & 0,235 & Valid \\
\hline 3 & 0,756 & 0,235 & Valid \\
\hline 4 & 0,615 & 0,235 & Valid \\
\hline 5 & 0,827 & 0,235 & Valid \\
\hline
\end{tabular}

Sumber: Data primer yang diolah tahun 2017 yang dilampirkan pada lampiran 15

Berdasarkan data pada tabel diatas, dapat dilihat bahwa tes essay sebanyak 5 soal $r$ hitung $>r$ tabel, maka soal tes essay dinyatakan valid, sehingga soal tersebut dapat digunakan sebagai instrumen untuk pengambilan data dalam penelitian ini. Hasil uji reliabilitas tes dapat dilihat pada tabel berikut ini:

Tabel 4.2 Hasil Uji Reliabilitas Soal Tes

\begin{tabular}{cccc}
\hline Jumlah Siswa & Nilai Alpha & Angka Kritis Reliabel & Hasil Uji \\
\hline 36 & 0,800 & 0,60 & Reliabel
\end{tabular}

Sumber: Data primer yang diolah tahun 2017 yang dilampirkan pada lampiran 16

Hasil pengujian reliabilitas menunjukkan bahwa semua butir soal dinyatakan reliabel. Sehingga data yang dihasilkan melalui uji reliabilitas ini dapat digunakan untuk proses analisis data dan uji statistik selanjutnya.

Uji Homogenitas

Penentuan responden dalam penelitian ini dibagi menjadi dua kelompok, yaitu kelas eksperimen 
dan kelas kontrol. Penentuan responden dilakukan dengan cara melakukan uji homogenitas terhadap populasi. Populasi diambil dari kelas X semester genap tahun ajaran 2016/2017di SMA Negeri 4 Jember yang terdiri dari delapan kelas yaitu X Mipa 1 sampai dengan X Sos 2. Penentuan homogenitas dari kedelapan kelas tersebut menggunakan analisis varian (ANAVA). Adapun nilai yang dijadikan untuk uji homogenitas adalah nilai ulangan harian pada kompetensi dasar lembaga jasa keuangan dalam perekonomian indonesia. Berikut ini adalah tabel hasil uji homogenitas dari kedelapan kelas:

Tabel 4.3 Uji Homogenitas

Test of Homogeneity of Variances

NILAI

\begin{tabular}{|c|c|c|c|}
\hline Levene Statistic & df1 & $\mathrm{df} 2$ & Sig. \\
\hline .591 & 7 & 275 & .763 \\
\hline
\end{tabular}

Sumber : Data primer yang diolah tahun 2017 yang dilampirkan pada lampiran 4

Dari hasil di atas dapat diketahui bahwa signifikansi sebesar 0,763. Karena signifikansi lebih besar 0,05 maka dapat disimpulkan bahwa hipotesis nol (Ho) diterima yaitu yang berarti tingkat kemampuan awal siswa sebelum dilakukan penelitian adalah sama (homogen). Sehingga peneliti selanjutnya melakukan undian, dari delapan kelas tersebut, yang digunakan sebagai sampel penelitian adalah kelas X Sos 1 dan kelas X Sos 2. Kelas X Sos 1 sebagai kelas Eksperimen yaitu pembelajaran yang menerapkan pendekatan saintifik, sehingga kelas X Sos 2 sebagai kelas Kontrol yaitu pembelajaran dengan menerapkan pendekatan konvensional. Uji test Hasil perhitungan $t_{\text {test }}$ dapat dilihat pada tabel di bawah ini:

Tabel 4.4 Hasil Uji $t_{\text {test }}$

\begin{tabular}{cccccc}
\hline $\mathrm{t}_{\text {test }}$ & $\mathrm{t}_{\text {tabel }}$ & Df & $\mathrm{A}$ & $\mathrm{M}_{\mathrm{x}}$ & $\mathrm{M}_{\mathrm{y}}$ \\
\hline 5,556 & 1,994 & 70 & $5 \%$ & 82,36 & 72,22
\end{tabular}

Sumber: Data primer yang diolah tahun 2017 yang dilampirkan pada lampiran 17

Berdasarkan perhitungan $t_{\text {test }}$ diperoleh harga $t_{\text {test }}=5,556$ kemudian dikonsultasikan dengan harga $t_{\text {tabel }}=1,994$. Harga $t_{\text {hitung }} 5,556 \geq t_{\text {tabel }} 1,994$. Berdasarkan data tersebut maka $t_{\text {tes }} \geq t_{\text {tabel }}$ sehingga dapat diterangkan bahwa ada perbedaan yang signifikan hasil belajar siswa antara penerapan pendekatan saintifik dengan penerapan pendekatan konvensional. Hasil belajar siswa pada kelas yang menerapkan pendekatan saintifik sebesar 82,36 dan hasil belajar pada kelas yang menerapkan pendekatan konvensional sebesar 72,22. Hal tersebut membuktikan bahwa hasil belajar siswa dengan pendekatan saintifik lebih tinggi dari pada pendekatan konvensional yaitu sebesar 10,14.

\section{Pembahasan}

Hasil akhir penelitian ini menunjukkan adanya perbedaan hasil belajar siswa yang signifikan antara pembelajaran dengan menerapkan pendekatan saintifik dan pembelajaran dengan menerapkan pendekatan konvensional. Hal tersebut dibuktikan dengan besar $t_{\text {hitung }}=5,556$ yang melebihi nilai $t_{\text {tabel }}$ $=1,994$ sehingga dapat disimpulkan bahwa terdapat perbedaan yang signifikan hasil belajar siswa pada kelas yang menerapkan pendekatan saintifik dengan siswa pada kelas yang menerapkan pendekatan konvensional. Hasil belajar siswa pada kelas yang menerapkan pendekatan saintifik sebesar 82,36 
sedangkan hasil belajar siswa pada kelas yang menerapkan pendekatan konvensional sebesar 72,22. Besar perbedaan hasil belajar siswa menunjukkan pembelajaran dengan pendekatan saintifik lebih tinggi jika dibandingkan dengan pembelajaran dengan pendekatan konvensional yaitu sebesar 10,14. Hal ini berarti pendekatan saintifik lebih efektif dibandingkan pendekatan konvensional dilihat dari hasil belajar siswa.

Penerapan pendekatan saintifik membuat siswa antusias dalam kegiatan pembelajaran yang sedang berlangsung, karena pendekatan saintifik ini membuka peluang siswa untuk berani mengungkapkan pendapatnya, mempertahankan pendapatnya dan menyanggah pendapat dari siswa lain. Pada pendekatan saintifik ini, siswa didorong untuk menemukan atau mengkonstruk konsep yang sedang dikaji melalui langkah-langkah mengamati, menanya, mencoba/menggali informasi, menalar dan mengkomunikasikan. Pendekatan saintifik merupakan pembelajaran yang membuat siswa termotivasi, membuat belajar lebih bermakna dengan menciptakan suasana belajar yang menyenangkan dan siswa terlibat langsung baik fisik maupun mental dalam proses pembelajaran. Hal ini sesuai dengan pendapat Machin (dalam Maryani dan Fatmawati, 2015), pembelajaran dengan pendekatan scientific merupakan suatu proses pembelajaran yang dirancang agar peserta didik secara aktif membangun konsep, hukum atau prinsip melalui tahapan-tahapan mengamati, merumuskan masalah, mengajukan atau merumuskan hipotesis, menumpulkan data dengan berbagai teknik, menganalisis data, menarik kesimpulan, dan mengkomunikasikan konsep, hukum atau prinsip yang "ditemukan".

Dalam pendekatan saintifik ini terdapat lima langkah yang menjadi dasar proses pembelajaran, yaitu mengamati (observing), menanya (questioning), mencoba (experimenting), menalar (associating), dan mengkomunikasikan (communicating). Kelima proses belajar secara scientific tersebut diimplementasikan pada saat memasuki kegiatan inti pembelajaran. dengan menggunakan pendekatan scientific ini, proses belajar mengajar menjadi tertib, antara lain adanya kerja sama yang baik antara siswa dengan kelompoknya misalnya dalam mengerjakan setiap tugas yang diberikan sehingga dapat mengembangkan keberanian dan keterampilan siswa dalam menjawab dan mengemukakan pendapat baik pada langkah menanya, menalar dan mengkomunikasikan pada saat diskusi berlangsung, meskipun ada beberapa siswa yang hanya menggantungkan temannya saja.

Pembelajaran dengan pendekatan saintifik akan mendorong siswa untuk mencari sendiri informasi-informasi yang mereka butuhkan, mereka tidak hanya memperoleh informasi dari guru saja, tetapi mereka dapat memperoleh informasi dari berbagai sumber, misalnya dari teman, dari pengalaman, dari observasi lingkungan sekitar dan dari internet, sehingga pendekatan saintifik ini akan membuat siswa lebih aktif dan mandiri. Hal ini sesuai dengan pendapat Fadlillah (2014: 175) yang menyatakan bahwa apa yang dipelajari dan diperoleh peserta didik dalam pendekatan saintifik ini dilakukan dengan indra dan akal pikiran sendiri sehingga mereka mengalami secara langsung dalam proses mendapatkan ilmu pengetahuan. Hasil wawancara peneliti dengan guru mata pelajaran ekonomi kelas X SMA Negeri 4 Jember mengenai pendekatan saintifik menunjukkan respon positif terhadap pembelajaran yang menerapkan pendekatan saintifik, karena pendekatan saintifik ini cukup menarik, dan dengan diterapkannya pendekatan saintifik ini siswa akan lebih aktif, mereka juga dapat mengungkapkan pendapat mereka di depan teman-temannya, mereka aktif berdiskusi dengan teman kelompoknya, sehingga mereka tidak akan mudah bosan dengan pembelajaran yang disampaikan oleh guru.

Pada kelas kontrol yang dalam pembelajarannya diterapkan pendekatan pembelajaran konvensional, siswa cenderung menjadi pendengar, mereka akan hanya mendengarkan penjelasan dari guru dan mencatat hal-hal yang mereka anggap penting. pembelajaran hanya berpusat pada guru, guru akan lebih banyak mengajarkan konsep-konsep saja, siswa tidak dituntut untuk aktif mengemukakan pendapat mereka, siswa juga tidak didorong untuk menemukan sendiri masalah-masalah yang ada dan 
memecahkan masalah tersebut. Hal ini sesuai dengan teori yang dikemukakan oleh Ujang Sukandi (dalam Gora dan Sunarto: 2010) yang menyatakan bahwa pendekatan konvensional ditandai dengan guru mengajar lebih banyak mengajarkan tentang konsep-konsep bukan kompetensi, tujuannya adalah siswa mengetahui sesuatu bukan mampu untuk melakukan sesuatu, dan pada saat proses pembelajaran, siswa lebih banyak mendengarkan. Hasil wawancara peneliti dengan guru mata pelajaran ekonomi kelas X SMA Negeri 4 Jember mengenai pendekatan konvensional menyatakan pendekatan konvensional jika dilakukan terus menerus dalam pembelajaran cukup membosankan bagi siswa. Karena siswa tidak ada aktivitas lain selain mendengarkan dan mencatat penjelasan dari guru, mereka tidak diberi kebebasan untuk mengemukakan pendapat didepan teman-temannya. Sehingga mereka akan muduh merasa bosan.

Hasil wawancara peneliti dengan siswa kelas X Sos 1 SMA Negeri 4 Jember mengenai pembelajaran dengan pendekatan konvensional mereka menyatakan kadang senang mengikuti pelajaran ekonomi, tetapi sering merasa bosan juga, karena hanya mendengarkan penjelasan dari guru, tidak ada variasi lain dalam pembelajaran.

\section{PENUTUP}

Kesimpulan dari penelitian ini adalah terdapat perbedaan yang signifikan hasil belajar siswa pada kelas ekspeimen yang menerapkan pendekatan saintifik, dengan hasil belajar siswa yang menerapkan pendekatan konvensional pada kompetensi dasar fungsi manajemen siswa kelas X di SMA Negeri 4 Jember Tahun Ajaran 2016/2017. Hasil belajar siswa menunjukkan ada perbedaan yang signifikan antara kelas yang menerapkan pendekatan saintifik dengan kelas yang menerapkan pendekatan konvensional, dimana hasil belajar siswa pada kelas yang menerapkan pendekatan saintifik lebih tinggi dibandingkan kelas yang menerapkan pendekatan konvensional.

Saran yang dapat peniliti sumbangkan sehubungan dengan penelitian tentang hasil belajar siswa di kelas X SMA Negeri 5 Jember adalah: guru diharapkan untuk mengurangi penggunaan pendekatan konvensional dalam kegiatan pembelajaran, guru dapat mengintensifkan penggunaan pendekatan saintifik (scientific approach) dalam pembelajaran serta menjadikan pendekatan tersebut sebagai salah satu pilihan dalam variasi mengajar, karena dilihat dari hasil belajar siswa pada kelas yang menerapkan pendekatan saintifik lebih tinggi dibanding dengan kelas yang menerapkan pendekatan konvensional, sehingga pendekatan saintifik lebih efektif dibanding pendekatan konvensional

\section{DAFTAR PUSTAKA}

Abidin, Y. 2014. Desain Sistem Pembelajaran Dalam Konteks Kurikulum 2013. Bandung: PT Refika Aditama.

Fadlillah. 2014. Implementasi Kurikulum 2013 Dalam Pembelajaran SD/MI, SMP/MTs, \& SMA/MA. Yogyakarta: Ar-Ruzz Media.

Gora, W dan Sunarto. 2010. PAKEMATIK Strategi Pembelajaran Inovatif Berbasis TIK. Jakarta: PT Elex Media Komputindo.

Majid, A. 2016. Strategi Pembelajaran. Bandung: PT Remaja Rosdakarya.

Maryani, I dan Fatmawati, L. 2015. Pendekatan Scientific dalam Pembelajaran di Sekolah Dasar: Teori dan Praktik. Yogyakarta: Deepublish.

Sani, R, A. 2015. Pembelajaran Saintifik Untuk Implementasi Kurikulum 2013. Jakarta: Bumi Aksara. 